\title{
Pediatric plastic surgery research needs in global health: A scoping review
}

\author{
Karen Y Chung ${ }^{*}$, Elizabeth L Dale ${ }^{2}$, Claudia Malic ${ }^{3}$, Louise Caouette-Laberge ${ }^{4}$, Steven Hanna $^{1}$, Scott Corlew $^{5}$ and Dan Poenaru ${ }^{6}$ \\ ${ }^{1}$ Queen's University School of Medicine, Kingston, Canada \\ ${ }^{2}$ Department of Plastic and Reconstructive Surgery, University of Tennessee College of Medicine, Chattanooga, Tennessee, USA \\ ${ }^{3}$ Department of Plastic Surgery, University of Ottawa, Ottawa, Canada \\ ${ }^{4}$ Department of Plastic Surgery, University of Montreal, Quebec, Canada \\ ${ }^{5}$ Former CMO, St. Thomas Rutherford Hospital, Tennessee, USA; former CMO, ReSurge International \\ ${ }^{6} \mathrm{McGill}$ University, Quebec, Canada
}

\begin{abstract}
Introduction: Plastic surgery in developing countries have focused on children for decades, however there is currently no formal literature review. This scoping review aimed to identify key themes and research gaps in global pediatric reconstructive surgical research to effectively guide future initiatives.

Methods: This was an IRB-approved scoping review of publications from EMBASE and MEDLINE between 2000 to 2013 relevant to pediatric plastic surgery in low-resource communities. Two independent investigators completed the primary review and three independent investigators completed the secondary review. Descriptive demographic data was collected.

Results: 106 studies were included. The majority came from Asia (57\%), followed by Africa (40\%) and Central/South America (11\%). The clinical domains were: burns $(n=50)$, cleft lip/palate (CLP, $n=32)$, general plastic surgery $(n=10)$, craniofacial $(n=6)$, flaps and grafts $(n=3)$, and hand surgery $(n=1)$. Burn publications stressed burn prevention (64\%) and public education (54\%) as needs. CLP research identified a need for monitoring/evaluating current programs (19\%) and increasing public awareness (19\%). General plastic surgery research emphasized a need for environmental hazard prevention $(60 \%)$. International agencies ( $\mathrm{n}=25)$ invited further research in developing local healthcare infrastructure, and monitoring/evaluating current projects.

Conclusions: A systematic review is welcome in pediatric burns and CLP. Hand surgeries, flaps/grafts, and other craniofacial anomalies are significantly underreported. A paucity of clinical research, and research from Central/South America remains. Emphasis on developing local infrastructure and evaluating current international volunteer missions is welcome. The significant gaps remaining in global pediatric plastic/reconstructive surgical research constitute opportunities for future international projects.
\end{abstract}

\section{Introduction}

Internationally, plastic surgery is making its mark as a necessary surgical specialty in Low and Middle Income Countries (LMICs). Plastic surgeons are uniquely qualified to address the burden of surgical disease in the developing world, most notably through management of burn injuries, facial congenital anomalies and traumatic injuries [1].

Children have been the focus for plastic surgeons who work in LMICs for decades. Early childhood age is associated with a disproportionately high incidence of burns, accidents and poorer outcomes [2-10]. The focus on children substantially improves outcomes for burns, traumatic injuries, and seriously debilitating congenital anomalies, notably cleft lip/palate (CLP) [11-15].

Despite the fact that resources were allocated for management of burns and congenital anomalies, the quality of care from foreign agencies is now a priority. Concerns with inappropriate follow-up, unsustainable funding, meeting the 'body count', i.e., operating on medically unfit children to meet a quota, significantly contributed to the movement towards surgical harm reduction. Since 2008, Operation Smile, Smile Train, and Resurge International were among the invested international non-governmental agencies that began to evaluate the quality of care provided [16-21].
While these examples are a clear indication of growing interest and research in this field, no formal review has been conducted. The objective of this scoping review is to identify key themes and research gaps in global pediatric reconstructive surgical research to effectively guide future initiatives.

\section{Methods}

This study was reviewed and approved by the institutional review board of Queen's University in Ontario, Canada. A scoping review was selected as the best research methodology that would meet the study's broad objective of identifying dominant themes and research needs. Since pediatric plastic surgery research in LMICs is a heterogeneous field where no formal review had previously been conducted,

Correspondence to: Karen Chung, Queen's University School of Medicine, 15 Arch Street, Kingston, ON, K7L 3N6, Canada, Tel: 905-719-7919; E-mail: kchung@qmed.ca

Key words: global health, global surgery, pediatric plastic surgery, pediatric burns, cleft lip/palate, international agencies

Received: July 03, 2016; Accepted: July 23, 2016; Published: July 26, 2016 
this method was also applied because it provided the flexibility of modifying inclusion/exclusion criteria post hoc. A systematic review and meta-analysis was deemed to not be an appropriate fit for a broad, heterogeneous field where a formal assessment of study quality would not be pertinent to this study's objectives. To guide the scoping review, the framework designed by Arksey and O’Malley [19] and modified by Levac, et al. [20]. There were four stages to this review process: (1) Establishing the question (2) Identifying and selecting relevant literature (3) Charting the data, and (4) Collating, summarizing and reporting the results.

Establishing the research question: A team-based approach was used to determine a broad research question with a clearly articulated scope of pediatric plastic surgery in LMICs. From this, a search strategy was devised using the following key terms: Burns, Cleft lip and/or Cleft Palate (CLP), Craniofacial Anomalies, Flaps and Grafts, Hand Trauma, General plastic surgery, and International Agencies. General plastic surgery referred to articles that covered more than one clinical domain of plastic surgery.

Identifying and selecting relevant literature: Our search was limited to English-language sources to reflect the language competency of the reviewers. An electronic bibliographic search in EMBASE and MEDLINE was conducted. A discussion at the beginning of the study determined the inclusion and exclusion criteria and it was updated as the study progressed. Table 1 lists the medical subject headings ( $\mathrm{MeSH})$ terms that were used.

Primary review: Two investigators (KC, SH) independently reviewed all documents and completed the data abstraction. The differences were resolved by two third investigators with extensive international surgical experience (DP, LCL). Inclusion criteria were as follows: plastic surgery focus, pediatric population, global health perspective, within 2000-2013. Articles needed to meet all inclusion criteria. Items were excluded if less than $20 \%$ of pediatric patients were involved, did not have a global health focus, was not in English or was not able to be retrieved.

\section{Secondary review - Data charting, collating, summarizing and reporting}

Prior to the secondary review, four investigators (ED, CM, LCL, DP) were provided with a sample of articles related to their field of clinical interest. Investigators identified the themes found in that sample. These themes were used in the secondary review by three investigators (KC,ED,CM). Themes were updated as the study progressed. Descriptive demographic characteristics were also collected at this time.

Data analysis: Analyses were performed only on the data from included studies. Demographic data, themes and research needs were summarized using basic descriptive statistics (simple counts and percentages).

\section{Results}

Figure 1 provides a flow diagram of the screening process. Only 106 studies satisfied the inclusion criteria after the initial literature review of 330 citations. Study demographic characteristics are summarized in Table 2. Twenty-six percent of the articles were authored by international agencies $(n=28)$, with the majority of articles published from local institutions $(n=78)$. Themes and research needs identified for Burns, CLP and International Agencies are summarized in Figure 2.

Burns: Publication distribution by continent is as follows: Asia (60\%), Africa (33\%), and Central/South America (3\%). Local institutions published $94 \%$ of the publications. Table 3 summarizes the distribution of publications by country. Sixty percent of burn publications focused on burn epidemiology. Burns in males were more common than in females. Of the total number of articles that reported incidence $(n=32), 28 \%$ reported higher burn incidence in females. Common risk factors included lower socioeconomic status, lower education, and crowded conditions [21-24]. Scald injury was reported to be the highest incidence for burns [6,24-26]. Fifty percent of publications indicated that children are at higher risk for burns than

Table 1. All search terms used for Medline and Embase.

\begin{tabular}{|c|c|}
\hline Subject of Review & Scope of the term \\
\hline What & $\begin{array}{l}\text { Plastic Surgery, Plastic Surgical Nursing, } \\
\text { Cleft*( cleft lip/ orcleft lip face palate/ orcleft lip nose/ orcleft lip palate/ orcleft palate/) } \\
\text { Craniofacial*( craniofacial development/ orcraniofacial malformation/ orcraniofacial surgery/) } \\
\text { Burn* } \\
\text { Hand*(hand injury/ orhand joint/ orhand malformation/), } \\
\text { Graft* ( full thickness skin graft/ orcomposite skin graft/ orfree tissue graft/ ormuscle graft/ ortissue graft/ orgraft dysfunction/ oracute graft } \\
\text { versus host disease/ oracute graft rejection/ orsplit thickness skin graft/ ornerve graft/orfree skin graft/ orgraft failure/ orskin graft/) }\end{array}$ \\
\hline Who & $\begin{array}{l}\text { Pediatric* (Pediatric/ Pediatric Surgery/ Pediatric Ward) } \\
\text { Child }<\text { unspecified age }> \\
\text { Infant }<\text { to one year }> \\
\text { Preschool Child }<1 \text { to } 6 \text { years }> \\
\text { School Child }<7 \text { to } 12 \text { years }> \\
\text { Adolescent }<13 \text { to } 17 \text { years }>\end{array}$ \\
\hline Where & LMIC (developing country/ lowest income group/ international cooperation/ public health/ rural health care/) \\
\hline When & $2000-2013$ \\
\hline Subject of Review & Scope of the term \\
\hline What & $\begin{array}{l}\text { Plastic Surgery (Surgery, Plastic) } \\
\text { Cleft* (Cleft Palate/ Cleft Lip) } \\
\text { Craniofacial*(Craniofacial Dysostosis/ Craniofacial Abnormalities) } \\
\text { Burn*(Burns, Chemical/ Burns/ Burns, Electric) } \\
\text { Hand* (Hand Deformities/ Hand) } \\
\text { Graft* (exp surgical flaps/ or exp free tissue flaps/ or exp perforator flap) }\end{array}$ \\
\hline Who & Pediatric* (Pediatrics/ OR Child (adolescent/child/ child, preschool/infant) \\
\hline Where & $\begin{array}{l}\text { Poverty* (Poverty/ Developing Countries) International Agencies (International agencies/ red cross/ united nations) } \\
\text { Rural Health (Rural Health) }\end{array}$ \\
\hline When & $2000-2013$ \\
\hline
\end{tabular}




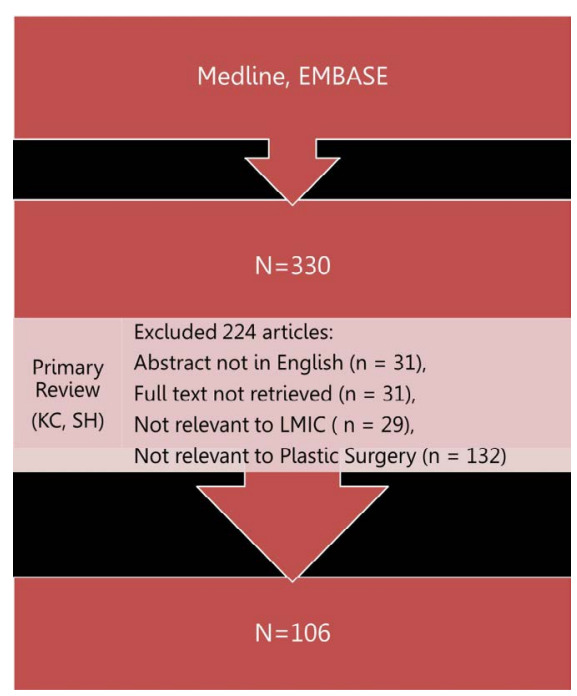

Figure 1. Flow Diagram of Search Strategy and Screening Process: Overview of inclusion criteria, exclusion criteria and final distribution of articles.

Table 2. Demographic summary of each clinical domain based on year, location, institution type and publication type.

\begin{tabular}{|c|c|c|}
\hline Type of demographic & Number of Studies & Percentage of Studies \\
\hline \multicolumn{3}{|l|}{ Publication Year } \\
\hline $2000-2007$ & 63 & $48 \%$ \\
\hline $2008-2014$ & 69 & $52 \%$ \\
\hline \multicolumn{3}{|l|}{ Clinical Domain } \\
\hline Burns & 50 & $47 \%$ \\
\hline Cleft Lip/Palate & 32 & $30 \%$ \\
\hline $\begin{array}{l}\text { General } \\
\text { (Greater than one domain) }\end{array}$ & 10 & $9 \%$ \\
\hline Craniofacial & 6 & $6 \%$ \\
\hline Flaps/Grafts & 3 & $3 \%$ \\
\hline Hand & 1 & $<1 \%$ \\
\hline No Clinical Focus & 4 & $4 \%$ \\
\hline \multicolumn{3}{|l|}{ Study Location } \\
\hline Asia & 62 & $45 \%$ \\
\hline Africa & 42 & $31 \%$ \\
\hline Central/ South America & 12 & $9 \%$ \\
\hline Other & 11 & $8 \%$ \\
\hline Not Stated & 10 & $7 \%$ \\
\hline \multicolumn{3}{|l|}{ Study Institution } \\
\hline International Agencies & 25 & $24 \%$ \\
\hline Local Institutions & 81 & $76 \%$ \\
\hline \multicolumn{3}{|l|}{ Study Design } \\
\hline Retrospective Cohort & 43 & $36 \%$ \\
\hline Editorials/ Letters/ Opinion Pieces & 18 & $15 \%$ \\
\hline Epidemiological Studies & 12 & $10 \%$ \\
\hline Case Reports & 11 & $9 \%$ \\
\hline Qualitative Research & 11 & $9 \%$ \\
\hline Prospective Cohort & 8 & $7 \%$ \\
\hline Audits & 7 & $6 \%$ \\
\hline Case-Control & 5 & $4 \%$ \\
\hline Reviews & 4 & $3 \%$ \\
\hline
\end{tabular}

adults, where the highest incidence in children occurred in those aged $0-5$ years $(n=17)$. Burn mortality ranged from $27-53.5 \%[27,28]$. Ideal management included carefully planned protocol [8]; immediate care [29]; open exposure, letting the burn dry out under the skin [24]; sevenflap-plasty for contractures [30] and; a figure-of- 8 sling for post burn axillary contractures [31]. Sixty-four percent of articles cited a need for burn prevention research and fifty-four percent of articles reported a need for public education. Effective burn prevention methods published included targeting those at higher risk, comic books for preschool children and local, culturally-sensitive workshops and public education programs [26,33-35].

Clefts: The majority of cleft articles are published in Asia (47\%), Africa (41\%), then Central and South America (9\%). International agencies published $29 \%$ of the articles $(n=12)$. Table 4 summarizes distribution by country. Sixty-six percent of articles focused on epidemiology and thirty-eight percent reported on the significance of multidisciplinary identified risk factors for cleft lip/palate (CLP, 38\%). Cleft lip/palate incidence in Asia ranges from 1.1 to 4.04/1000 live births [12,13,36,37], Africa $0.18 / 1000$ to $5 / 1000[37,38]$, the highest reported in the Wudoaba community of Ghana [37], and Central America from 1 to $2 / 1000$ [39,40]. Mean age of repair ranged from 3.7 months [37] to 9.9 years [41]. Age of presentation ranged from zero to sixty-two years of age [36,41-44]. Cleft incidence in males is more common than in females, with left unilateral cleft lip occurring more frequently [41-44].

Thirty-eight percent of articles discussed preventative and risk factors. Preventative factors include folic acid and other micronutrients $[40,45]$. Risk factors reported include genetics, low socioeconomic status, teratogenic agents, nicotine poisoning, and exposure to organic solvents, radiation and alcohol $[40,44,46]$. Genes identified include Msh homeobox 1, forkhead box protein E1, and interferon regulatory factor [39].

The dominant research gaps identified were: critical and constructive monitoring and evaluation of current cleft programs (19\%), increasing public awareness and education (19\%), targeting risk factors for cleft prevention (16\%) and further discussion on appropriate surgical technique (9\%). Interventional trials that target CLP risk factors are encouraged, specifically one that applies the use of folic acid $[40,45]$. There is indication that early repair of both lip and palate in one surgical session is not inferior in outcome to the traditional staged procedure [11]. Millard and Tennison have been cited as favored techniques for cleft lip, and Langenbeck-Wardill or Dorrance techniques for cleft palate $[39,47]$.

\section{General plastic surgery}

General plastic surgery articles emphasized environmental hazards to children $(60 \%)$ and identified public education as a research need (20\%).

\section{International agencies}

Twenty-four percent of the articles were authored by international agencies $(n=25)$. The majority of publications came from international aid in Asia (44\%). Table 5 summarizes the distribution of publications by International Agency. Multidisciplinary teams were emphasized. International Agency benefits included financial support $[39,48,49]$, good quality surgical care $[18.39,48-50,53]$, training $[14,18,50]$ and empowerment of local communities [14,18,39,50,52] $(\mathrm{n}=19)$. Recommendations included incorporating local leadership $[14,15,17,36,51]$, teaching $[14,17]$, sustainable follow up $[17,39,52]$. Standardized monitoring and evaluation [17,39,53,54] $(\mathrm{n}=15)$. Limitations cited from these publications included interfering with the local healthcare system, selection of sites based on volunteer preference rather than site need [14,15], lack of appropriate follow up and monitoring [36,55], and the infamous 'body count [14-16,39,49] $(\mathrm{n}=10)$. Articles identified the following as a research need: public education $[14,17,48,55]$, development of sustainable local healthcare 

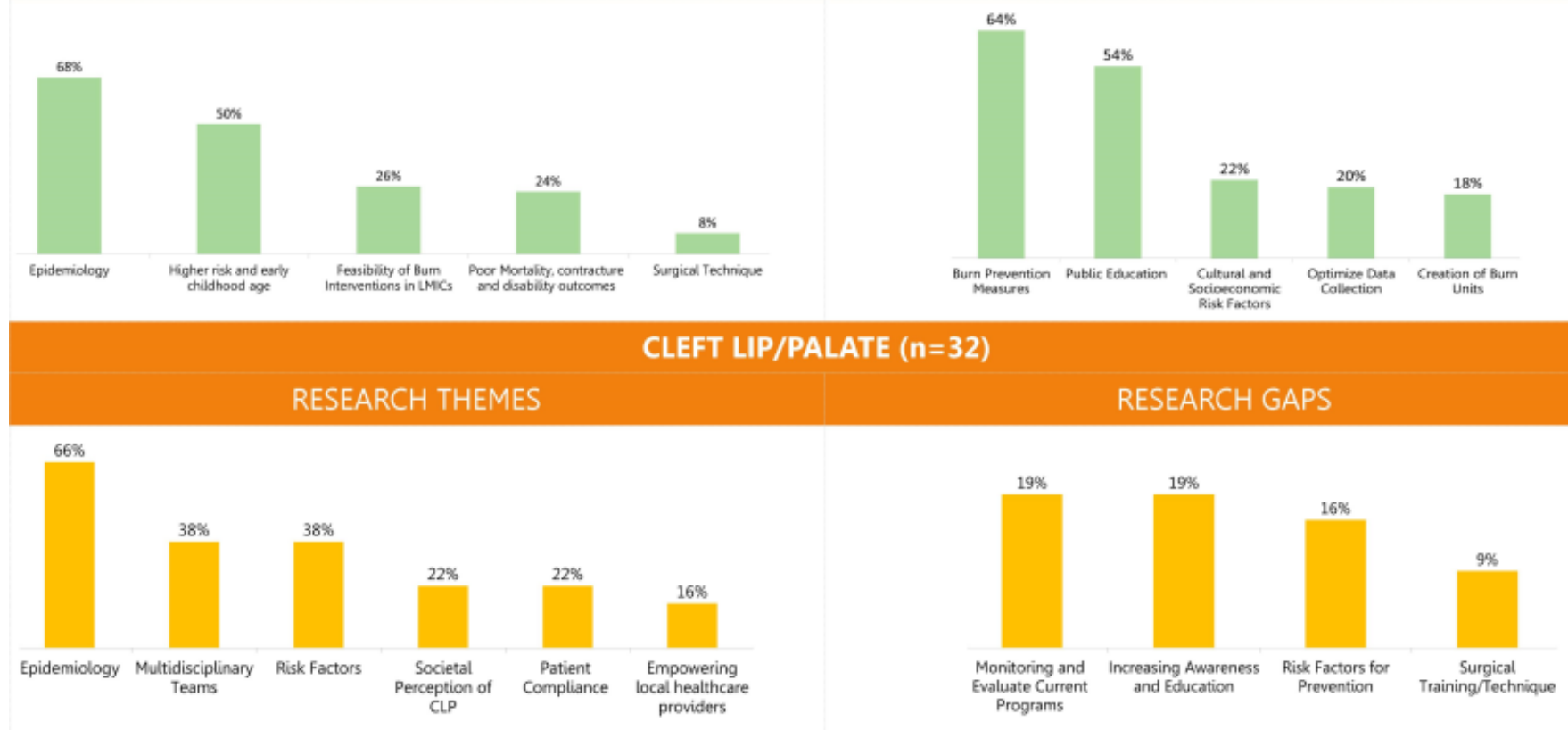

INTERNATIONAL AGENCIES $(n=25)$
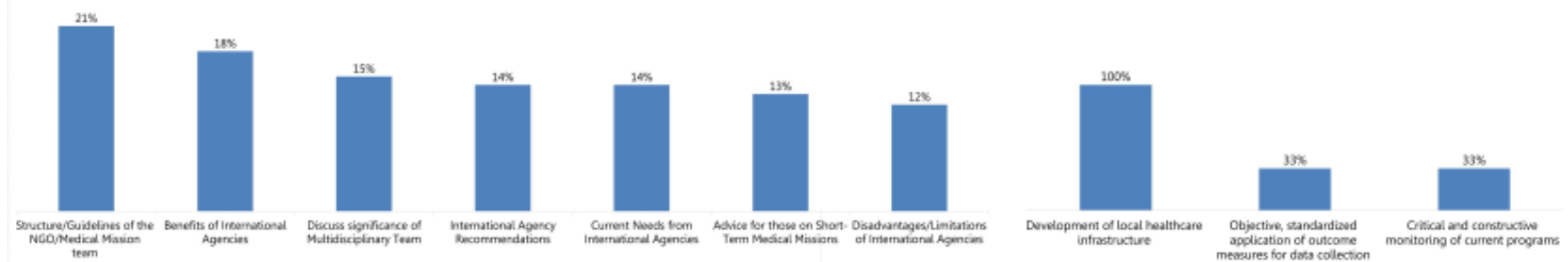

Figure 2. Major Research Themes and Gaps: Summary of major research themes and research gaps for Burns, Cleft Lip/Palate and International Agencies. Research gaps refer to the needs identified by the publications.

infrastructure [14-18,36,39,50-52] and standardized monitoring and evaluation $(n=10)[17,39,53,54]$.

\section{Discussion}

The majority of research articles came from Asia and Africa. It appears that local institutions in India, South Africa and Bangladesh have been producing the most research. This also demonstrates that they have centers with appropriate infrastructure for research activity. These higher resource centers can consider building a foundation in prospective studies, randomized control trials or even experimental labs using local resources, based on identified research gaps. An example for a project could be instituting injury prevention measures in a small community and testing the incidence of traumatic injury thereafter. This will likely require international partnerships to successfully complete and may be an effective direction of resources. These centers also have the opportunity to collaborate with centers that have no research activity or fewer publications within their country. There is an obvious need for research articles from Central/South America, and LMICs from other continents not previously mentioned. Reasons for this are speculative, but epidemiological research to identify prevalence would be an appropriate start.
The majority of publications in global pediatric plastic and reconstructive surgery focus on burns and cleft surgery/pathology, provide the foundation for a systematic review and meta-analysis of literature in pediatric burns and cleft research in LMICs. In lowresource settings, research comes at an additional cost to already limited and stretched supplies and resources. However, an interesting difference in the two areas focuses on who is studying the condition. A vast majority of burn research is published by local practitioners (94\%) rather than international agencies. While the majority of cleft lip/palate articles are also published by local practitioners, it is a much smaller majority at $62.5 \%$. The relative abundance of local interest in burn pathology related articles suggest that local practitioners find it worth focusing their efforts to study and report this. This may be because the care for burn wounds is more complex, takes longer and has a significant impact on appearance and function. In comparison, local cleft related literature is bolstered by international or resourced interest. It may be due to better marketing from well-established agencies that have engendered sympathetic donors, providing a wealth of resources for both provision of care and education.

Another interesting finding is that both the burns category and the general plastic surgery category focus on injury prevention as a need. 
Table 3. Number of Burn Publications Distributed by Country.

\begin{tabular}{|c|c|c|}
\hline Location & Organization & Number of Publications \\
\hline India & $\begin{array}{l}\text { Chistian Medical Hospital, LokNayak Hospital,Forensic Medicine Hospital, Multi-centre; KanchiKamakoti } \\
\text { CHILDS Trust Hospital, Government Medical College }\end{array}$ & 7 \\
\hline South Africa & $\begin{array}{l}\text { Edendale Hospital; Red Cross Children's; Chris Hani Baragwanath; UNISA Institute, Medical Research } \\
\text { Council, Karolinska Institute }\end{array}$ & 7 \\
\hline Bangladesh & Karolina Institute; Faridpur Institute; Multi-centre & 6 \\
\hline Pakistan & Aga Khan University Hospital; Aman Hospital;Multi-centre & 4 \\
\hline Iran & Department of Public Health; Tehran University of Medical Sciences & 3 \\
\hline Sri Lanka & Multi-Centre, National Hospital of Sri Lanka & 3 \\
\hline Egypt & Multicentre; Ain Shams University & 2 \\
\hline Kenya & Kenyatta National Hospital; Kijabe Hospital & 2 \\
\hline Nigeria & Lagos State University; Ahamdu Bello University Teaching Hospital & 2 \\
\hline World Database & Karolinska Institute; Prince of Wales Hospital & 2 \\
\hline Afghanistan & Hospital (Red Cross) & 1 \\
\hline China & People's Liberation Army Hospital & 1 \\
\hline Iraq & Red Cross & 1 \\
\hline Malawi & Kamzumu Central Hospital & 1 \\
\hline Mozambique & Multi-centre & 1 \\
\hline New Zealand & Middlemore Hospital & 1 \\
\hline Oman & Khoula Hospital Burns Unit & 1 \\
\hline Peru & National Institute of Child Health Hospital & 1 \\
\hline Sao Tome and Principe & STP Central Hospital & 1 \\
\hline Sierra Leone & Multi-Centre & 1 \\
\hline Singapore & Raja IsteriPengiranAnakSaleha Hospital & 1 \\
\hline Sudan & Elfasher\& Khartoum Bahr Teaching Hospital & 1 \\
\hline Turkey & Baskent University Adana Hospital & 1 \\
\hline Vietnam & BG UnfallklinikLudwingshafen & 1 \\
\hline Yemen & King Faisal University & 1 \\
\hline
\end{tabular}

Table 4. Number of CLP Publications Distributed by Country.

\begin{tabular}{|c|c|c|}
\hline Location & Organization & Number of Publications \\
\hline India & Multi-centre; Operation Smile; Smile Train Project; Sri Ramachandra University & 5 \\
\hline N/A & Multi-centre; Operation Smile & 4 \\
\hline Nigeria & Lagos State University and Hospital; Author Specific & 3 \\
\hline Bangladesh & Multi-centre & 2 \\
\hline Cambodia & Children's Surgical Center & 2 \\
\hline China & Operation Smile; University of Hong Kong & 2 \\
\hline Ghana & KomfoAnokye Teaching Hospital & 2 \\
\hline Africa & Multi-centre & 1 \\
\hline America, Argentina, Guatemala & Rotaplast International & 1 \\
\hline Brazil & Interplast & 1 \\
\hline Columbia & Healing the Children & 1 \\
\hline Democratic Republic of Congo & Doctors on Call for Service Learning Centre (DOCS LC) of Goma in the DRC & 1 \\
\hline Iraq & Operation Smile & 1 \\
\hline Mexico & Author Specific & 1 \\
\hline Nepal & Author Specific & 1 \\
\hline Vietnam & Japanese Cleft Palate Foundation & 1 \\
\hline Wales (low SES) & Author Specific & 1 \\
\hline Zambia & Zambia University Teaching Hospital & 1 \\
\hline
\end{tabular}

While the exact environments of small children are quite varied across the globe, it is clear that children are susceptible to injury. This type of research therefore, would need to be site-specific, with investigations into the direct causes of injury and the development and study of locally applicable interventions.

The epidemiology and prevalence of CLP is more established with clear variation within continents. Identification of higher incidence areas, such as that in Ghana's Wudoaba community discovered lead to more effective direction of future research and intervention to improve outcomes. A controlled trial or prospective review exploring interventions that target CLP risk factors in LMICs is highly recommended $[40,44,46]$. Another research gap emphasized for cleft lip and palate is the monitoring of current programs. A prominent concern is that the ethics and safety of these missions should be evaluated. Quality improvement a vital aspect of most hospitals in highincome countries, and it is refreshing that there is a concern that charity programs need to be viewed critically as well. This theme is echoed by a more specific review of the articles published by international agencies $[56,57]$.

The substantial research deficiencies in craniofacial defects, flaps, grafts and pediatric hand surgeries compared to pediatric burns and cleft lip/palate may direct future allocation of resources. The paucity 
Table 5. Number of Publications Distributed by International Agency.

\begin{tabular}{|l|c|c|}
\hline Organization & Location(s) & Nicaragua, Iraq \\
\hline Operation Smile & China, Sri Lanka & India \\
\hline ReSurge/Interplast & N/A \\
\hline Smile Train & Mexico, City, Mexico \\
\hline Volunteers in Plastic Surgery & UK \\
\hline A Thousand Smiles & Columbia \\
\hline Facing the World & Sokoto, Nigeria \\
\hline Healing the Children & South Vietnam \\
\hline International Noma Project & Bolivia \\
\hline Japanese Cleft Palate Foundation & India \\
\hline MACLA: Medical Aid for Children of Latin America & China \\
\hline Northern Cleft Foundation & 1 \\
\hline Smile China & Honduras, Cambodia \\
\hline Sterling Bunnell Traveling Fellowship & Bangladesh \\
\hline University of Insubria, Varese, Italy & India \\
\hline World Craniofacial Foundation & Manaus, Brazil \\
\hline Yale School of Medicine & 1 \\
\hline
\end{tabular}

of pediatric hand surgery research in global health is significant and is likely under-reported given the high incidence of trauma in developing countries. This warrants further investigation because of the lifelong handicap for children with severe hand injuries. It would be worthwhile to investigate the epidemiology of pediatric hand surgery cases in LMICs to establish need.

Development of sustainable local healthcare infrastructure is emphasized as an area for future research for international agencies [14]. Quality evaluation and assessment are essential in order to maximize the care provided to vulnerable children in resource-poor situations $[16,17,19,58]$. Invested international agencies have recently begun to report on the quality of care provided. To maximize care quality, Volunteers in Plastic Surgery (VIPS) has developed pediatric plastic surgical guidelines to be used as a framework for short-term surgical missions [56,57].

\section{Limitations}

First, the scope of the literature available likely does not reflect the extent of global need because of deficiencies in infrastructure, training, follow-up and financial support needed for local surgeons to report the activities at their hospital. Although this emphasizes the need for this review to streamline future research efforts, readers should be aware that other research gaps likely exist. Second, although this review can be cited as an international review, the scope was unfortunately limited to articles published in English. Future international research collaborations inclusive of other languages is recommended. Third, the depth of this review was also limited due to the very nature of the scoping review methodology. This compromise was needed in order to focus on mapping prevalent research themes and gaps. A focused systematic review in a more homogenous field such as burns or cleft lip/palate would be worthwhile. Lastly, a significant number of articles were not able to be retrieved because of limited access to specific journals which included those not published in English.

\section{Conclusions}

The majority of publications in global pediatric plastic and reconstructive surgery focus on burns and cleft surgery. Epidemiological research has been well-reported in these domains and it would be worthwhile to conduct experimental and clinical trials in these fields. Clinical domains that are likely under-reported include pediatric hand trauma, the use of flaps and grafts and other craniofacial anomalies. Epidemiological research from Central/South America would be welcome. Emphasis on developing local infrastructure and evaluating current international volunteer missions is appreciated. The significant gaps remaining in global pediatric plastic/reconstructive surgical research constitute opportunities for future international projects. The authors would be happy to provide all the references included in this scoping review to promote international collaboration in streamlining research efforts.

\section{Acknowledgements}

There were no other contributors other than the authors listed. No writing assistance was provided. There were no funding sources.

\section{Conflicts of interests}

None.

\section{References}

1. Semer NB, Sullivan SR, Meara JG (2010) Plastic surgery and global health: How plastic surgery impacts the global burden of surgical disease. J Plast Reconstr Aesthetic Surg 63: 1244-1248.

2. Ahmed N, Andersson R (2002) Differences in cause-specific patterns of unintentional injury mortality among 15-44-year-olds in income-based country groups. Accid Anal Prev 34: 541-551. [Crossref]

3. Batra AK (2003) Burn mortality: recent trends and sociocultural determinants in rura India. Burns 29: 270-275. [Crossref]

4. Chandra Paul A, Swapan KB, Spronk CA, Niemeijer RP, Spauwen PH (2008) Postburn contracture treatment: a healthcare project in Bangladesh. Burns 34: 181-184. [Crossref]

5. Chinnock PI (2004) Cochrane Injuries Group. Inj Prev 10: 291-291.

6. de Sousa Petersburgo D, Keyes CE, Wright DW, Click LA, Macleod JB, et al. (2010) The epidemiology of childhood injury in Maputo, Mozambique. Int J Emerg Med 3: 157-163. [Crossref]

7. Hankins CL, Tang XQ, Phipps A (2006) Hot beverage burns: an 11-year experience of the Yorkshire Regional Burns Centre. Burns 32: 87-91. [Crossref]

8. Hashmi M, Kamal R (2013) Management of patients in a dedicated burns intensive care unit (BICU) in a developing country. Burns 39: 493-500. [Crossref]

9. Herbert HK, van As AB, Bachani AM, Mtambeka P, Stevens KA, et al. (2012) Patterns of pediatric injury in South Africa: an analysis of hospital data between 1997 and 2006. J Trauma Acute Care Surg 73: 168-174. [Crossref]

10. Agrawal K, Panda K (2011) A modified surgical schedule for primary management of cleft lip and palate in developing countries. Cleft Palate Craniofac J 48: 1-8. [Crossref] 
11. Onah II, Opara KO, Olaitan PB, Ogbonnaya IS (2008) Cleft lip and palate repair: the experience from two West African sub-regional centres. $J$ Plast Reconstr Aesthet Surg 61: 879-882. [Crossref]

12. Patil SB, Kale SM, Khare N, Math M, Jaiswal S, et al. (2011) Changing patterns in demography of cleft lip-cleft palate deformities in a developing country: the Smile Train effect--what lies ahead? Plast Reconstr Surg 127: 327-332.

13. Portier-Marret N, Hohlfeld J, Hamedani M, de Buys Roessingh AS (2008) Complete bilateral facial cleft (Tessier 4) with corneal staphyloma: a rare association. J Pediatr Surg 43: e15-18. [Crossref]

14. Corlew S, Fan VY (2011) A model for building capacity in international plastic surgery: ReSurge International. Ann Plast Surg 67: 568-570. [Crossref]

15. Dupuis CC (2004) Humanitarian missions in the third world: a polite dissent. Plast Reconstr Surg 113: 433-435. [Crossref]

16. Geraghty TE, Towle DR, Hendrix KD (2003) Medical aid for children of Latin America: reconstructive plastic surgery in developing countries. Mo Med 100: 24-26. [Crossref]

17. Gosain AK, Salyer KE, Arnaud E (2009) Long-term solutions for the delivery of craniofacial care in India and the developing world. J Craniofac Surg 20 Suppl 2: 16421646. [Crossref]

18. Hachach-Haram N, Benyon SL, Eccles SJ, Kirkpatrick WN, Kelly M, et al. (2012) Facing the World: audit of activity 2002-2010. J Plast Reconstr Aesthet Surg 65: 13121324. [Crossref]

19. Arksey H, O'Malley L (2005) Scoping studies: towards a methodological framework. Int J Soc Res Methodol 8: 19-32.

20. Levac D, Colquhoun H, O'Brien KK (2010) Scoping studies: advancing the methodology. Implement Sci 5: 69. [Crossref]

21. Ahmed N, Andersson R (2002) Differences in cause-specific patterns of unintentional injury mortality among 15-44-year-olds in income-based country groups. Accid Anal Prev 34: 541-551. [Crossref]

22. Batra AK (2003) Burn mortality: recent trends and sociocultural determinants in rural India. Burns 29: 270-275. [Crossref]

23. Delgado J, Ramírez-Cardich ME, Gilman RH, Lavarello R, Dahodwala N, et al. (2002) Risk factors for burns in children: crowding, poverty, and poor maternal education. Inj Prev 8: 38-41. [Crossref]

24. Gosselin RA, Kuppers B (2008) Open versus closed management of burn wounds in a low-income developing country. Burns 34: 644-647. [Crossref]

25. Hyder AA, Sugerman DE, Puvanachandra P, et al. (2009) Global childhood unintentional injury surveillance in four cities in developing countries: A pilot study. Bull World Health Organ 87: 345-352.

26. Van Niekerk A, Menckel E, Laflamme L (2010) Barriers and enablers to the use of measures to prevent pediatric scalding in Cape Town, South Africa. Public Health Nurs 27: 203-220. [Crossref]

27. Abrol A, Saraf R, Singh S (2005) Thermal and electrical burns in jammu province. $J K$ Science 7: 87-89.

28. Carini L, Grippaudo FR, Bartolini A (2005) Epidemiology of burns at the Italian Red Cross Hospital in Baghdad. Burns 31: 687-691. [Crossref]

29. Prasanna M, Mishra P, Thomas C (2004) Delayed primary closure of the burn wounds. Burns 30: 169-175. [Crossref]

30. Suliman MT (2004) Experience with the seven flap-plasty for the release of burns contractures. Burns 30: 374-379. [Crossref]

31. Obaidullah, Ullah H, Aslam M (2005) Figure-of-8 sling for prevention of recurrent axillary contracture after release and skin grafting. Burns 31: 283-289. [Crossref]

32. Mashreky SR, Rahman A, Chowdhury SM, Giashuddin S, Svanström L, et al. (2008) Consequences of childhood burn: findings from the largest community-based injury survey in Bangladesh. Burns 34: 912-918. [Crossref]

33. Potokar TS, Prowse S, Whitaker IS, Ali S, Chamania S (2008) A global overview of burns research highlights the need for forming networks with the developing world. Burns 34: 3-5. [Crossref]
34. Sinha I, Patel A, Kim FS, Maccorkle ML, Watkins JF (2011) Comic books can educate children about burn safety in developing countries. J Burn Care Res 32: e112-117. [Crossref]

35. Mathangi RK, Jayaraman V, Andal A, Shanker J, Ramachandran P (2004) Paediatric rehabilitation in a developing country-india in relation to aetiology, consequences and outcome in a group of 459 burnt children. Pediatr Rehabil 7: 145-149.

36. Gupta K, Bansal P, Dev N, Tyagi SK (2010) Smile Train project: a blessing for population of lower socio-economic status. J Indian Med Assoc 108: 723-725. [Crossref]

37. Agbenorku P, Ansah S, Acheampong A, Sabbah D, Bankas D, et al. (2011) Komfo Anokye Teaching Hospital Multidisciplinary Cleft Clinic. J Craniofac Surg 22: 532536. [Crossref]

38. Abenavoli FM (2005) Operation Smile humanitarian missions. Plast Reconstr Surg 115: 356-357. [Crossref]

39. MacIntosh RB, Herman LT, Shivapuja PK, Echeverri-Arguello RC (2013) Volunteer cleft surgery in Colombia: an 18-year perspective. J Oral Maxillofac Surg 71: 1742 1751. [Crossref]

40. Acuna-Gonzalez G, Medina-Solis CE, Maupome G, et al. (2011) Family history and socioeconomic risk factors for non-syndromic cleft lip and palate: A matched casecontrol study in a less developed country. Biomedica 31: 381-391.

41. Longombe AO, Tshimbila Kabangu JMV (2012) The epidemiological approach of clefts lip and palate in the eastern of democratic republic of congo. [Les fentes labiopalatines a l'est de la Republique Democratique du Congo. Aspects epidemiologiques.] Ann Chir Plast Esthet 57: 245-249.

42. Donkor P, Bankas DO, Agbenorku P, Plange-Rhule G, Ansah SK (2007) Cleft lip and palate surgery in Kumasi, Ghana: 2001-2005. J Craniofac Surg 18: 1376-1379. [Crossref]

43. Schwarz R, Bhai Khadka S (2004) Reasons for late presentation of cleft deformity in Nepal. Cleft Palate Craniofac J 41: 199-201. [Crossref]

44. Omo-Aghoja VW, Omo-Aghoja LO, Ugboko VI, Obuekwe ON, Saheeb BD, et al. (2010) Antenatal determinants of oro-facial clefts in Southern Nigeria. Afr Health Sci 10: 31-39. [Crossref]

45. Tolarová MM, Poulton D, Aubert MM, Oh H, Ellerhorst T, et al. (2006) Pacific Craniofacial Team and Cleft Prevention Program. J Calif Dent Assoc 34: 823-830. [Crossref]

46. Durning P, Chestnutt IG, Morgan MZ, Lester NJ (2007) The relationship between orofacial clefts and material deprivation in wales. Cleft Palate Craniofac J 44: 203-207.

47. Sankale AA, Ndiaye A, Baillet A, Ndiaye L, Ndoye M (2012) [Management of nasolabial clefts: the issue in Dakar]. Ann Chir Plast Esthet 57: 250-253. [Crossref]

48. Magee WP Jr (2010) Evolution of a sustainable surgical delivery model. J Craniofac Surg 21: 1321-1326. [Crossref]

49. Marck KW (2003) Noma: should we care? Br J Plast Surg 56: 522-523. [Crossref]

50. Faga A, Scevola D, Mezzetti MG, Scevola S (2000) Sulphuric acid burned women in Bangladesh: a social and medical problem. Burns 26: 701-709. [Crossref]

51. Goldstein MH (2000) Creating long-term benefits in cleft lip and palate volunteer missions. Plast Reconstr Surg 106: 517.

52. Lau YS (2006) An insight into burns in a developing country: a Sri Lankan experience. Public Health 120: 958-965. [Crossref]

53. McQueen KA, Burkle J, Al-Gobory ET, Anderson CC (2007) Maintaining baseline, corrective surgical care during asymmetrical warfare: A case study of a humanitarian mission in the safe zone of a neighboring country. Prehosp Disaster Med 22: 3-7.

54. McQueen KA, Magee W, Crabtree T, Romano C, Burkle J (2009) Application of outcome measures in international humanitarian aid: Comparing indices through retrospective analysis of corrective surgical care cases. Prehosp Disaster Med 24: 39-46.

55. Marcus E (2004) Surgical correction of cleft lip and palate. N Engl J Med 351: 26582659.

56. Politis GD, Schneider WJ, Van Beek AL, et al. (2011) Guidelines for pediatric perioperative care during short-term plastic reconstructive surgical projects in less developed nations. Anesth Analg 112: 183-190. 
57. Schneider WJ, Migliori MR, Gosain AK, Gregory G, Flick R (2011) Volunteers in Plastic Surgery Guidelines for Providing Surgical Care for Children in the Less Developed World: Part II. Ethical Considerations. Plast Reconstr Surg 128: 216e-22e.
58. Ruiz-Razura A, Cronin ED, Navarro CE (2000) Creating long-term benefits in cleft lip and palate volunteer missions. Plast Reconstr Surg 105: 195-201. [Crossref]

Copyright: $\odot 2016$ Chung KY. This is an open-access article distributed under the terms of the Creative Commons Attribution License, which permits unrestricted use, distribution, and reproduction in any medium, provided the original author and source are credited. 